\title{
INFLUENCE OF LYS198ASN POLYMORPHISM OF ENDOTHELIN-1 GENE ON ISCHEMIC ATHEROTHROMBOTIC STROKE CHARACTERISTICS
}

DOI: $10.36740 /$ WLek202004106

\author{
Tetiana B. Oleshko, Iryna S. Chaika, Tetiana M. Oleshko, Viktoriia Yu. Harbuzova \\ SUMY STATE UNIVERSITY, SUMY, UKRAINE
}

\begin{abstract}
The aim: Investigate the effect of Lys198Asn polymorphism of the EDN1 gene on ischemic atherothrombotic stroke characteristics.

Materials and methods: Venous blood of 170 patients with ischemic atherothrombotic stroke (IAS) and 124 patients without cerebrovascular pathology, who made up the control group, used for the study. Lys198Asn (rs5370) polymorphism of the EDN1 gene was determined by the polymerase chain reaction method followed by restriction fragment length analysis. Statistical analysis was performed using SPSS-17.0. The values of $\mathrm{P}<0.05$ were considered reliable.

Results: An association between the Lys198Asn polymorphism of the EDN1 gene and the IAS development was detected. For Asn/Asn genotype carriers, the risk of IAS developing is 4 times higher than that of homozygotes for the major allele. The association of this polymorphism with the arterial pool, whose atherothrombotic changes lead to the development of IAS, was found in individuals with BMI $<25 \mathrm{~kg} / \mathrm{m}^{2}$. Lys198Asn polymorphism also affects the severity of IAS in persons with hypertension and non-smokers. Conclusion: The Lys198Asn polymorphism of the EDN1 gene influences some characteristics of ischemic stroke.
\end{abstract}

KEY WORDS: ischemic stroke, endothelin-1, gene polymorphism

Wiad Lek. 2020;73(4):657-661

\section{INTRODUCTION}

Ischemic stroke is one of the most common forms of cerebrovascular disorders and occupies a leading position in the morbidity and mortality of the population worldwide, and is therefore an important medical and social problem. It has been proved that endothelial dysfunction plays a key role in the mechanisms of ischemic stroke development, so this issue has recently become of great importance, has been actively researched by scientists all over the world, and its relevance has not subsided over the years [1]. Endothelial dysfunction is defined as an imbalance in the production system and the functioning of numerous vascular factors that lead to disorders of the homeostasis of the vascular wall [2]. Endothelin-1 is an important regulator of vascular wall metabolism [3]. Interacting with specific endothelin type A receptors, endothelin-1 exerts its potent vasoconstrictor effect, also promotes cell proliferation, adhesion, fibrosis, stimulation of free radical formation and thrombosis, indicating not only the effect on blood pressure, but also a key role in the progression of endothelial disorders $[4,5]$.

The functioning of endothelin-1, of course, is determined by the structural features of its gene. Therefore, the study of the role of the single-nucleotide polymorphism of the endothelin-1 gene (EDN1) in the development of ischemic atherothrombotic stroke (IAS) is of great importance.

The essence of the Lys198Asn (rs5370) polymorphism of the EDN1 gene lies in the replacement of guanine $(\mathrm{G})$ purine by pyrimidine thymine $(\mathrm{T})$ at the 5665 th position of the gene, which is reflected on the 61th nucleotide of the 5 th exon and leads to amino acid replacement of lysine by asparagine in the 198th protein codon [6]. The presence of a minor allele at this polymorphic site is known to be associated with a higher level of endothelin-1 in blood plasma [7], and the Lys/Lys genotype is associated with its lowest level [8]. The investigated polymorphic variant of the EDN1 gene plays an important role in the development of endothelial dysfunction and is involved in the pathogenesis of a number of cardiovascular [9] and, in particular, cerebrovascular diseases $[10,11]$.

\section{THE AIM}

The aim of the study was to investigate the association of Lys198Asn allelic polymorphism of the EDN1 gene with ischemic atherothrombotic stroke development.

\section{MATERIALS AND METHODS}

Venous blood of 170 patients with IAS ( $42.4 \%$ of women and $57.6 \%$ of men) aged 40 to 85 years (mean age of $(64.7 \pm 0.73$ ) years) was used for the study. The ischemic nature of the stroke was established on the basis of anamnesis and clinical picture of the disease, the results of CT-study of the brain. The pathogenetic variant of the stroke was determined according to the TOAST criteria based on the anamnesis data, the clinical course of the disease, the results of the ul- 
trasound doppler of the major arteries of the head, and the electrocardiogram [12]. Patients with lacunar, cardioembolic ischemic stroke and ischemic stroke of unclear etiology were excluded from the experimental group.

The control group comprised 124 persons $(36.3 \%$ women and $63.7 \%$ men, average age was $76.7 \pm 0.93$ years) without the history of stroke or other acute cerebrovascular pathologies, myocardial infarction and other atherosclerosis complications were included to the control group. The groups did not differ in the ratio of two sexes $(\mathrm{P}=0.294$ for the $\chi^{2}$-test), but the average age of the control group (76.7 \pm 0.93 years) was significantly higher than that of the experimental one $(\mathrm{P}<0.001)$ (Table I).

The work was performed in accordance with the principles of the Helsinki Declaration of the World Medical Association "Ethical Principles of Medical Research with the Involvement of a Human being as a Research Object", Order No. 690 of the Ministry of Health of Ukraine (dated September 23, 2009) and approved by the Bioethics Commission of the Medical Institute of Sumy State University. Prior to engaging in the study, all participants provided written informed consent.

For genotyping, venous blood was collected under sterile conditions in $2.7 \mathrm{ml}$ monovets with potassium salt of ethylenediaminetetraacetic acid (Sarstedt, Germany), frozen and stored at $-20^{\circ} \mathrm{C}$. Lys198Asn (rs5370) polymorphism of the $E D N 1$ gene was determined by polymerase chain reaction (PCR) method followed by restriction fragment length analysis. The region of the specified gene was amplified using a pair of specific primers [13]. For amplification, 50-100 ng of DNA was taken and added to a mixture containing $5 \mu \mathrm{l}$ of 5-fold PCR buffer, $1.5 \mathrm{~mm}$ of magnesium sulfate, $200 \mu \mathrm{M}$ of a mixture of four nucleotide triphosphates, $20 \mathrm{pM}$ of each primer and 1.0 U of Taq-polymerase («Thermo Scientific», USA), the volume was adjusted to $25 \mu \mathrm{l}$ with deionized water.

PCR was performed in a GeneAmp PCR System 2700 thermocycler («Applied Biosystems», USA). Amplification of the fragment of the 5 th exon consisted of 35 cycles: denaturation $-94{ }^{\circ} \mathrm{C}(60 \mathrm{~s})$, hybridization of primers $-61^{\circ} \mathrm{C}(60 \mathrm{~s})$ and elongation $-72{ }^{\circ} \mathrm{C}(45 \mathrm{~s})$. For restriction 2 units of restriction enzyme Cac81 («Thermo Scientific», USA) were used. If guanine was contained in the 5665 position of the EDN1 gene, the amplifier, consisting of 262 base pairs, was cleaved by Cas 81 restriction enzyme into two fragments -189 and 73 base pairs. In case of replacement of guanine with thymine, the restriction site for Cac81 was lost and one fragment of size 262 base pairs was formed (Fig. 1). The amplifications after restriction were separated in $2.5 \%$ agarose gel containing ethidium bromide. Horizontal electrophoresis $(0.13 \mathrm{~A} ; 160 \mathrm{~V})$ was performed for 35 minutes. DNA visualization after electrophoresis was performed using a transilluminator (Biocom, Russia). Statistical analysis was performed using SPSS-17.0. The values of $\mathrm{P}<0.05$ were considered reliable.

\section{RESULTS AND DISCUSSION}

The genotyping of control group individuals by Lys198Asn polymorphism of the EDN1 gene allowed to establish the ratio of homozygotes by major allele (Lys/Lys), heterozygotes (Lys/Asn) and homozygotes by minor allele (Asn/Asn), which amounted to $63.7 .0 \% ; 32.3 \%$ and $4.0 \%$ respectively (Table II). The frequency of the major (Lys) allele was 0.8 and of the minor (Asn) was 0.2. Palagnyuk et al., examining the distribution of genotypes according to this polymorphism in the inhabitants of Podilskyi region of Ukraine, found that the frequency of the minor allele among the surveyed persons was equal to 0.202 [14], which coincides with our data. Similar results were obtained in the writings of other scientists for different populations. Maver et al. studied the distribution of allelic variants of the EDN1 gene by the Lys198Asn polymorphic site among the population of Slovenia [15]. According to the data obtained, the ratio of homozygotes by major allele (Lys/Lys), heterozygotes (Lys/Asn) and homozygotes for minor allele (Asn/Asn) among almost healthy individuals was equal to 62,$1 ; 34.2$ and $3.7 \%$ respectively. The frequency of the minor allele was 0.21 and did not differ significantly from the control group of the Ukrainian population $(\mathrm{P}>0.05)$. Scientists led by Gampenrieder examined the genotype frequency of Lys/Lys, Lys/Asn and Asn/Asn in the Austrian population, which was $63.8 ; 30.5$ and $5.7 \%$, respectively [16]. The frequency of the minor allele was 0.21 and also had no statistical differences with the Ukrainian population. The same results were obtained by Okan et al. for Turkish residents, genotype distribution among them was: Lys/Lys - 61.2\%, Lys/Asn - 34.9\% and Asn/Asn - 3.9\%. The minor allele was encountered at a frequency of 0.21 [17].

In terms of genotype distribution in the IAS patient group, it looks like this. Homozygotes by major allele (Lys/ Lys) $-48.2 \%$, heterozygotes (Lys/Asn) - 39.4\%, homozygotes by minor allele (Asn/Asn) - 12.4\%. Comparison of the data obtained with the results of genotyping of control group members showed that there is a reliable association between the IAS development and Lys198Asn allelic variants of the EDN1 gene, which makes this genetic factor an important predictor of endothelial dysfunction and cardiovascular disease development $\left(\chi^{2}=9.757 ; \mathrm{P}=0.008\right)$. This conclusion is confirmed by the fact that in the homozygotes for the minor allele Lys198Asn polymorphic site of the endothelin-1 gene, the risk of IAS development is 4 times higher than in the homozygotes for the major allele $(\mathrm{P}=0.07 ; \mathrm{OR}=4.046)$.

For other populations, Japanese researchers led by Yamaguchi have suggested that the impact of gene polymorphisms associated with atherothrombotic cerebral infarction may differ between women and men, and may depend on the presence or absence of traditional risk factors for atherosclerosis. According to multivariable logistic regression analysis adjusted for age, BMI, smoking, arterial hypertension, hypercholesterolemia and diabetes, Lys198Asn polymorphism of the EDN1 gene has significant association with ischemic atherothrombotic stroke in women. However, no such association was found in men [18]. Aslan et al. the effect of Lys198Asn polymorphism of the EDN1 gene on the development of ischemic stroke in a Turkish population was studied. There were no significant 


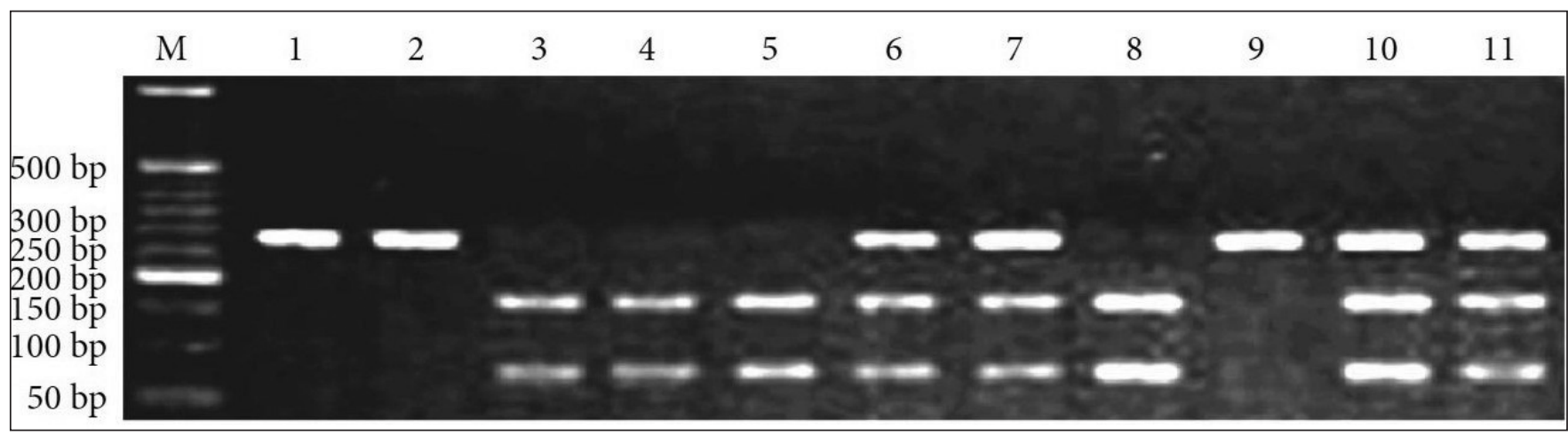

Figure 1: Results of EDN1 rs5370 polymorphism restriction analysis. M-molecular marker (bp-base pairs); lanes 3, 4, 5, and 8- Lys/Lys genotype; lanes 6, 7, 10, and 11- Lys/Asn genotype; lanes 1, 2, and 9-Asn/Asn genotype.

Table I. General characteristics of the study population.

\begin{tabular}{|c|c|c|c|}
\hline Indicator & $\begin{array}{l}\text { Patients with IAS } \\
\qquad(n=170)\end{array}$ & $\begin{array}{l}\text { Control group } \\
\quad(n=124)\end{array}$ & $\mathbf{P}$ \\
\hline Age, years & $64,7 \pm 0,73$ & $76,7 \pm 0,93$ & $<0,001$ \\
\hline Sex, female/male & $72 / 98$ & $45 / 79$ & $0,294^{*}$ \\
\hline Body weight (f), kg & $77,6 \pm 1,42$ & $69,8 \pm 1,8$ & 0,001 \\
\hline Body weight $(\mathrm{m}), \mathrm{kg}$ & $82,6 \pm 1,33$ & $75,7 \pm 1,77$ & 0,002 \\
\hline Height (f), cm & $163,6 \pm 0,65$ & $156,1 \pm 1,26$ & $<0,001$ \\
\hline Height $(\mathrm{m}), \mathrm{cm}$ & $172,9 \pm 0,76$ & $167,2 \pm 0,96$ & $<0,001$ \\
\hline $\operatorname{BMI}(f), k g / m^{2}$ & $29,0 \pm 0,54$ & $28,7 \pm 0,77$ & 0,744 \\
\hline $\mathrm{BMI}(\mathrm{m}), \mathrm{kg} / \mathrm{m}^{2}$ & $27,6 \pm 0,41$ & $27,0 \pm 0,55$ & 0,355 \\
\hline Systolic BP, mmHg & $167 \pm 2,3$ & $152,6 \pm 2,1$ & $<0,001$ \\
\hline Diastolic BP, mmHg & $95,4 \pm 1,2$ & $86,3 \pm 1,1$ & $<0,001$ \\
\hline Fasting glucose, $\mathrm{mmol} / \mathrm{L}$ & $5,92 \pm 0,12$ & $5,29 \pm 0,06$ & $<0,001$ \\
\hline
\end{tabular}

Note: $\mathrm{n}$ - number of patients; $\mathrm{f}$ - women; $\mathrm{m}$ - men; BMI - body mass index; BP - blood pressure; $\mathrm{P}$ - the statistical significance of differences;

* - according to the $\times 2$ criterion.

associations between this polymorphic site and the likelihood of stroke, and no significant changes in the results were taken into account such risk factors as smoking, alcohol consumption, hypertension and diabetes mellitus [19].

The study of the effect of Lys198Asn polymorphism on the main characteristics of IAS yielded the following results (Table III).

The development of IAS may be associated with lesions: 1) anterior, middle, and posterior cerebral arteries; 2) vertebral and basilar arteries, and 3) combined variants when multiple arteries from the above two groups are affected. The obtained results show that there is no dependence between the genotype of patients under studied polymorphism on the one hand and the areas of the arterial pool whose atherothrombotic changes lead to IAS - on the other (Table III). This pattern persists after taking into account gender differences, hypertension, and smoking. Somewhat different results were found in the distribution of IAS patients into subgroups depending on BMI. In subjects with BMI $<25 \mathrm{~kg} / \mathrm{m}^{2}$, the ratio of homozygotes by major allele (Lys/Lys), heterozygotes (Lys/Asn) and homozygotes by minor allele (Asn/Asn) with lesions of the anterior, middle, posterior cerebral arteries was $46.9 ; 46.9$ and $6.3 \%$, with lesions of the vertebral and basilar arteries 40.0; 60.0 and $0 \%$, and patients with the combined option -25.0 ; 0 and $75.0 \%$ respectively. Therefore, a statistically significant association of Lys198Asn polymorphism with the IAS arterial pool in individuals with $\mathrm{BMI}<25 \mathrm{~kg} / \mathrm{m}^{2}\left(\chi^{2}=16.998\right.$; $\mathrm{P}=$ $0.002)$ was detected. In subjects with BMI $\geq 25 \mathrm{~kg} / \mathrm{m}^{2}$, the frequency of allelic variants in this polymorphic variant was not statistically significant $\left(\chi^{2}=2.853 ; \mathrm{P}=0.583\right)$.

The severity of the clinical course distinguish IAS: mild, moderate and severe. The analysis showed the absence of association of Lys198Asn single nucleotide polymorphism with the severity of IAS. It has also not been identified taking into account such risk factors as gender and BMI. Taking into account the influence of hypertension revealed the following. In subjects with normal blood pressure, there was no association between the Lys198Asn polymorphic variant and the severity of IAS $\left(\chi^{2}=\right.$ 3.577; $\mathrm{P}=0.466$ ). Among individuals with hypertension who underwent IAS of varying severity, genotype distribution was as 
Table II. Distributions of genotypes and alleles in case and control groups.

\begin{tabular}{ccc}
\hline & Control & IAS \\
\hline Lys/Lys, $n$ (\%) & $79(63,7)$ & $82(48,2)$ \\
\hline Lys/Asn, $n(\%)$ & $40(32,3)$ & $67(39,4)$ \\
\hline Asn/Asn, $n$ (\%) & $5(4,0)$ & $21(12,4)$ \\
\hline Lys-allel & 0,8 & 0,68 \\
\hline Asn-allel & 0,2 & 0,32 \\
\hline$X^{2}$ & & 9,757 \\
\hline$P$ & & 0,008 \\
\hline
\end{tabular}

Note: $\mathrm{n}$ - number of patients; $\mathrm{P}$ - statistical significance of the difference according to the Pearson $\mathrm{X}$-criterion

Table III. Effect of Lys198Asn polymorphic variants of the EDN1 gene on the main IAS characteristics

\begin{tabular}{|c|c|c|c|}
\hline \multirow{2}{*}{$\begin{array}{c}\text { IAS characteristics } \\
\text { According to the arterial pool }\end{array}$} & \multicolumn{3}{|c|}{ Genotype } \\
\hline & Lys/Lys & Lys/Asn & Asn/Asn \\
\hline Anterior, middle and posterior cerebral arteries & $65(49,2 \%)$ & $53(40,2 \%)$ & $14(10,6 \%)$ \\
\hline Vertebral and basilar arteries & $10(41,7 \%)$ & $10(41,7 \%)$ & $4(16,7 \%)$ \\
\hline Combined variants & $7(50,0 \%)$ & $4(28,6 \%)$ & $3(21,4 \%)$ \\
\hline \multicolumn{4}{|c|}{$X^{2}=2,339 ; P=0,674$} \\
\hline According to the severity of the clinical course & Lys/Lys & Lys/Asn & Asn/Asn \\
\hline Mild & $33(60,0 \%)$ & $15(27,3 \%)$ & $7(12,7 \%)$ \\
\hline Moderate & $31(47,0 \%)$ & $29(43,9 \%)$ & $6(9,1 \%)$ \\
\hline Severe & $18(36,7 \%)$ & $23(45,6 \%)$ & $8(16,3 \%)$ \\
\hline \multicolumn{4}{|c|}{$X^{2}=7,249 ; P=0,123$} \\
\hline By recurrence & Lys/Lys & Lys/Asn & Asn/Asn \\
\hline Primary & $48(45,7 \%)$ & $44(41,9 \%)$ & $13(12,4 \%)$ \\
\hline Recurrent & $34(52,3 \%)$ & $23(35,4 \%)$ & $8(12,3 \%)$ \\
\hline \multicolumn{4}{|c|}{$X^{2}=0,795 ; P=0,672$} \\
\hline According to clinical manifestations & Lys/Lys & Lys/Asn & Asn/Asn \\
\hline Movement disorders & $2(50,0 \%)$ & $2(50,0 \%)$ & 0 \\
\hline Sensory disorders & $9(32,1 \%)$ & $16(57,1 \%)$ & $3(10,7 \%)$ \\
\hline Sensory-motor disorders & $71(51,4 \%)$ & $49(35,5 \%)$ & $18(13,0 \%)$ \\
\hline \multicolumn{4}{|c|}{$X^{2}=5,291 ; P=0,259$} \\
\hline
\end{tabular}

Note: The frequency of genotypes in absolute values and percentages is given. P- statistical significance of the difference according to the Pearson X2-criterion.

follows: mild - Lys/Lys - 58.5\%, Lys/Asn - 31.7\% and Asn/Asn - 9.8\%; moderate $-44.0 ; 50.0$ and $6.0 \%$; severe $-27.0 ; 51.4$ and $21.6 \%$, respectively $\left(\chi^{2}=11.278 ; \mathrm{P}=0.024\right)$. Thus, in homozygotes for minor alleles with hypertension, severe IAS was more common than mild or moderate.

Among those with no smoking habits, the genotype ratio (Lys/Lys, Lys/Asn, Asn/Asn) with a mild clinical course was $65.9 ; 24.4 ; 9.8 \%$, moderate $-46.8 ; 44.7 ; 8.5 \%$ and severe $-28.1 ; 53.1 ; 18.8 \%\left(\chi^{2}=11.369 ; \mathrm{P}=0.023\right)$. Therefore, a significant association of endothelin-1 gene polymorphism with the severity of IAS in non-smokers was found. However, the results of this association were not reliable in smokers $\left(\chi^{2}=1.078 ; \mathrm{P}=0.888\right)$. This suggests that smoking is such a significant risk factor that the impact of genetic factors on the severity of the clinical course of IAS is not significant and may mask the association between the studied polymorphism and stroke.
According to the results of the studies presented in Table III, Lys198Asn polymorphism of the EDN1 gene does not affect the incidence of recurrent cases of ischemic atherothrombotic stroke. Patients with significant risk factors such as gender, BMI, arterial hypertension, and smoking did not influence stroke recurrence.

The association of genotype of patients with Lys198Asn polymorphism with neurological manifestations of IAS was also investigated. The results of the analysis revealed the absence of dependence of the characteristics of the neurological picture of IAS from this polymorphic site. The main risk factors were not taken into account $(\mathrm{P} \otimes 0.05)$.

\section{CONCLUSIONS}

The genotype ratios of the endothelin-1 gene polymorphism studied were significantly different in patients with 
IAS and in control subjects. It is revealed that the Asn/Asn genotype carriers have a 4 times higher risk of developing IAS. The Lys198Asn polymorphic site of the EDN1 gene influences the characteristics of ischemic atherothrombotic stroke. The association of this polymorphism with the arterial pool, whose atherothrombotic changes lead to the development of IAS, was found in individuals with BMI < $25 \mathrm{~kg} / \mathrm{m}^{2}$. Lys 198 Asn polymorphism also affects the severity of IAS in persons with hypertension and non-smokers.

\section{REFERENCES}

1. Schepankevich L.A., Pilipenko P.I. Ishemicheskiy insult: otsenka parametrov sosudisto-trombotsitarnogo zvena gemostaza v ostrom periode zabolevaniya. Vestn. nevrol., psihiatr. i neyrohirur. 2011;1:11-13.

2. Rajendran P., Rengarajan T., Thangavel J. et al. The Vascular Endothelium and Human Diseases. International Journal of Biological Sciences. 2013;9(10):1057-1069.

3. Ambrosova T. N. Endotelialnaya disfunktsiya pri gipertonicheskoy bolezni. Mezhdunarodnyiy meditsinskiy zhurnal. 2013;4:16-21.

4. Koyama Y. Endothelin systems in the brain: involvement in pathophysiological responses of damaged nerve tissues. BioMolecular Concepts. 2013;4(4):335-347.

5. Oleshko T.B., Obukhova 0.A., Oleshko T.M. et al. Role of $C+70 \mathrm{G}$ single nucleotide polymorphism of endothelin receptor $A$ gene in the development of ischemic atherothrombotic stroke. Wiadomości Lekarskie. 2017;71;4:725-730.

6. Wróbel-DudziNska D., Kosior-Jarecka E., Aukasik U. et al. Risk Factors in Normal-Tension Glaucoma and High-Tension Glaucoma in relation to Polymorphisms of Endothelin-1 Gene and Endothelin-1 Receptor Type A Gene. Journal of Ophthalmology. 2015; Article ID 368792.

7. Palahniuk H. 0. Ratio of endothelin-1 and c-type natriuretic peptide concentrations in men with hypertensive disease of different severity. the regulatory role of polymorphism of the endothelin- 1 gene. Galician Medical Journal. 2016;23(3). D0I: 10.21802/gmj.2016.3.48.

8. Pahomya N.S., Uryasev 0.M., Shahanov A.V. Rol polimorfizmov nekotoryih genov $\mathrm{v}$ realizatsii arterialnoy gipertenzii. Zemskiy Vrach. 2014;3-4(24):21-24.

9. Taylor M.R.G., Slavov D., Humphrey K. et al. Pharmacogenetic effect of an endothelin-1 haplotype on response to bucindolol therapy in chronic heart failure. Pharmacogenetics and Genomics. 2009;19(1):35-42.

10. Gallek M., Alexander S.A., Crago E. et al. Endothelin-1 gene polymorphisms influence cerebrospinal fluid endothelin-1 levels following aneurysmal subarachnoid hemorrhage. Biol. Res. Nurs. 2015;17(2):185-190.

11. Gormley K., Bevan S., Hassan A. et al. Polymorphisms in genes of the endothelin system and cerebral small-vessel disease. Stroke. 2005;36(8):1656-1660.

12. Kadojić D., Dikanović M., Bitunjac M., Vuletić V., Čengić L., Bijelić B.R. Epidemiology of stroke. Periodicum Biologorum. 2012;114(3):253-257.

13. Dubovyk Ye.l., Oleshko T.B., Harbuzova V.Yu., Ataman A.V. Positive Association between EDN1 rs5370 (Lys198Asn) Polymorphism and Large Artery Stroke in a Ukrainian Population. Disease Markers. 2018;Article ID 1695782;9 pages. doi:10.1155/2018/1695782.

14. Palahniuk H. 0., Zhebel V. M. Spadkovo obumovleni osoblyvosti plazmovoi kontsentratsii endotelinu-1 u cholovikiv iz hipertonichnoiu khvoroboiu ta khronichnoiu sertsevoiu nedostatnistiu. Aktualni pytannia farmatsevtychnoi i medychnoi nauky ta praktyky. 2016;3(22):80-86.
15. Maver A., Medica I., Salobir B. et al. Lack of association of immuneresponse-gene polymorphisms with susceptibility to sarcoidosis in Slovenian patients. Genetics and Molecular Research. 2010;9(1):58-68.

16. Gampenrieder S.P., Hufnagl C., Brechelmacher S. et al. Endothelin-1 genetic polymorphism as predictive marker for bevacizumab in metastatic breast cancer. The Pharmacogenomics Journal. 2016:1-7. D0l:10.1038/tpj.2016.25.

17. Okan G., YildizZ., Gökdemir G. et al. G-231A and G+70C polymorphisms of endothelin receptor type-A gene could affect the psoriasis area and severity index score and endothelin 1 levels. E-ljd Basic Research. 2015;60(2):211.

18. YamaguchiS.,Yamada Y,Metoki N. etal.Genetic risk for atherothrombotic cerebral infarction in individuals stratified by sex or conventional risk factors for atherosclerosis. International Journal of Molecular Medicine. 2006;18:871-883.

19. Aslan 0., Gurger M., Atescelik M. et al. Endothelin-1 Lys198Asn and rs 10478694 polymorphism in ischemic stroke. Biomedical Research. 2017:28(2):750-754.

The presented work was performed within the framework of the topic of scientific research on state budget financing "Relationship of allelic polymorphism "Genes of ectopic calcification" with the development of widespread cardiovascular diseases and their complications", № states registration $0115 U 000688$.

\section{ORCID and contributionship:}

Tetiana B. Oleshko - 0000-0002-5909-5812 ${ }^{A, B, D}$

Iryna S. Chaika - 0000-0003-4786-2671 $1^{A, B}$

Tetiana M. Oleshko - 0000-0002-2229-2839 ${ }^{B, C}$

Viktoriia Yu. Harbuzova - 0000-0001-7183-6997 E,F

\section{Conflicts of interest:}

Authors declare no conflict of interest.

\section{CORRESPONDING AUTHOR Tetiana B. Oleshko}

st. Sanatornaya 31, Sumy, Ukraine

tel: +380994008389

e-mail: t.oleshko@med.sumdu.edu.ua

Received: 01.10 .2019

Accepted: 17.02 .2020

A - Work concept and design, $\mathbf{B}$ - Data collection and analysis, $\mathbf{C}-$ Responsibility for statistical analysis, D-Writing the article, $\mathbf{E}$-Critical review, $\mathbf{F}$-Final approval of the article 